\title{
Study of the $\mathrm{Nb}_{2} \mathrm{O}_{5}$ Insertion in $\mathrm{ZnO}$ to Dye-sensitized Solar Cells
}

\author{
Tatiana Lima Valerio $^{a}{ }^{\circledR}$, Guilherme Arielo Rodrigues Maia ${ }^{b}$ Letícia Fernanda Gonçalves $^{a}{ }^{\mathbb{D}}$,

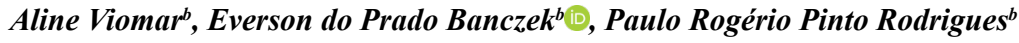 \\ aPrograma de Pós-Graduação em Bioenergia (PPGB), Universidade Estadual do Centro Oeste, \\ Guarapuava, PR, Brasil \\ ${ }^{b}$ Departamento de Química, Universidade Estadual do Centro Oeste, Guarapuava, PR, Brasil
}

Received: December 08, 2018; Revised: April 18, 2019; Accepted: May 19, 2019

\begin{abstract}
Dye-sensitized solar cells (DSSC) have received much attention as an alternative to silicon-based solar cells, due to various advantages. Zinc oxide $(\mathrm{ZnO})$ is an n-type semiconductor employed as photoanode on DSSC. The decrease of charge recombination is an efficient strategy capable of improving the photovoltaic performance of the device. In this perspective, $\mathrm{Nb}_{2} \mathrm{O}_{5}$ was added on $\mathrm{ZnO}$ solar cells. The oxides were characterized by the X-ray diffraction (XRD), Fourier-transform infrared spectroscopy (FTIR) and X-ray fluorescence (XRF). The photovoltaic parameters were obtained through J-V plots and photocronoamperometry. The results showed that the niobium oxide obtained presented orthorhombic crystal structure and DSSC with the addition of niobium oxide showed better efficiency, of $1.42 \%$ when compared the device with only $\mathrm{ZnO}$.
\end{abstract}

Keywords: DSSC, charge recombination, photovoltaic device.

\section{Introduction}

Dye-sensitized solar cells (DSSC) or Grätzel cells have attracted increasing attention due to mainly low cost, relatively high efficiency, easy fabrication, and flexibility. DSSC is dispositive of solar energy conversion into electrical energy, which involves a semiconductor oxide/dye interface ${ }^{1,2,3}$.

Recently, $\mathrm{ZnO}$, with similar band gap $(3.37 \mathrm{eV})$ to the $\mathrm{TiO}_{2}(3.2 \mathrm{eV})$, appears as an alternative material for the fabrication of high-efficiency DSSC ${ }^{4,5,6}$. The $\mathrm{ZnO}$ present higher electron mobility and electronic conductivity when compared to $\mathrm{TiO}_{2}$, such faster electron transport should in principle favor efficient collection of injected electrons at the device electrode, thereby minimizing interfacial charge recombination losses to either dye cations or oxidized redox species in the electrolyte and improving device performance ${ }^{7,8}$.

In an attempt to improve electric conduction and minimize the dark current, several materials have been explored for this purpose, such as $\mathrm{Al}_{2} \mathrm{O}_{3}, \mathrm{Nb}_{2} \mathrm{O}_{5}, \mathrm{ZrO}_{2}, \mathrm{SnO}_{2}, \mathrm{In}_{2} \mathrm{O}_{3}$ and $\mathrm{CeO}_{2}{ }^{9,10}$. In photovoltaic devices the $\mathrm{Nb}_{2} \mathrm{O}_{5}$ forms an energy barrier due to its energy gap being larger when compared to other semiconductors, causing the increase of the open circuit potential, thus suggesting the reduction in the speed of the reactions of charge recombination ${ }^{11,12,13}$. For that reason $\mathrm{Nb}_{2} \mathrm{O}_{5}$ layers have also been used as blocking layers of other oxides, preventing electron back-transfer ${ }^{14}$. Therefore, the present work aims to study $\mathrm{ZnO} / \mathrm{Nb}_{2} \mathrm{O}_{5}$ the mixture in dye-sensitized solar cells.

\section{Material and Methods}

\subsection{Obtaining and characterization of niobium pentoxide $\left(\mathrm{Nb}_{2} \mathrm{O}_{5}\right)$}

The $\mathrm{Nb}_{2} \mathrm{O}_{5}$ were prepared using the Pechini method adapted from previous procedures reported in the literature ${ }^{15}$. Started with ethylene glycol under constant stirring under $70^{\circ} \mathrm{C}$ and was added the citric acid until complete dissolution. The ammoniacal complex of niobium $\left(\mathrm{NH}_{4} \mathrm{H}_{2}\left[\mathrm{NbO}\left(\mathrm{C}_{2} \mathrm{O}_{4}\right)_{3}\right] \cdot \mathrm{nH}_{2} \mathrm{O}\right)$ was added slowly and the solution remained under constant stirring for $30 \mathrm{~min}$. After that sample, it was calcined by $4 \mathrm{~h}$ at $350^{\circ} \mathrm{C}$ and macerated and then was calcined by $700^{\circ} \mathrm{C}$ by $4 \mathrm{~h}$ with a heating rate of $2{ }^{\circ} \mathrm{C} / \mathrm{min}$. The characterization was made in a Fourier transform double-beam infrared spectrophotometer, Agilent Technologies, Cary 600 Series FTIR spectral band spectral range from $2500 \mathrm{~cm}^{-1}$ to 400 $\mathrm{cm}^{-1}$, with a $10 \% \mathrm{KBr}$ insert. For the structural identification of the oxides, the X-ray analysis was performed in the range of $10-75^{\circ}$, on the Bruker D2 Phaser DRX apparatus, with $\mathrm{CuK} \alpha$ radiation of $1.54 \AA$ at $30 \mathrm{kV}, 10 \mathrm{~mA}$, scanning speed of $0.07^{\circ} \mathrm{s}^{-1}$ and LynxEye detector.

\subsection{Preparation of the zinc oxide $(\mathrm{ZnO})$ films with niobium pentoxide $\left(\mathrm{Nb}_{2} \mathrm{O}_{5}\right)$}

The films were prepared by adding the $\mathrm{Nb}_{2} \mathrm{O}_{5}$ to commercial $\mathrm{ZnO}$ (SIGMA-ALDRICH, 99+\%) in the proportion of $5 \% \mathrm{~m} / \mathrm{m}$. The percentage was confirmed with X-ray 
fluorescence (XRF), on the X-MET7500 series handheld $\mathrm{XRF}$ analyzer in $40 \mathrm{kV}$ and $10 \mathrm{~mA}$. For the preparation of films was used $3.0 \mathrm{~g}$ of the oxides mixture $(2.85 \mathrm{~g} \mathrm{ZnO}$ and $0.15 \mathrm{~g} \mathrm{Nb}_{2} \mathrm{O}_{5}$ ), $0.1 \mathrm{~mL}$ of polyethylene glycol, $0.1 \mathrm{~mL}$ of Triton X-100, $0.1 \mathrm{~mL}$ acetylacetone $99.5 \%$ and $4 \mathrm{~mL}$ of deionized $\mathrm{H}_{2} \mathrm{O}$. The deposition was performed by the doctor blade method adapted to FTO conductive glass. After deposition the film was brought to the temperature of 450 ${ }^{\circ} \mathrm{C}$ so that all the organic material was removed and only the oxide $\left(\mathrm{ZnO} / \mathrm{Nb}_{2} \mathrm{O}_{5}\right)$ deposited in the FTO.

\subsection{Composition of the dye-sensitized solar cell (DSSC)}

The cell scheme is shown in Figure 1.

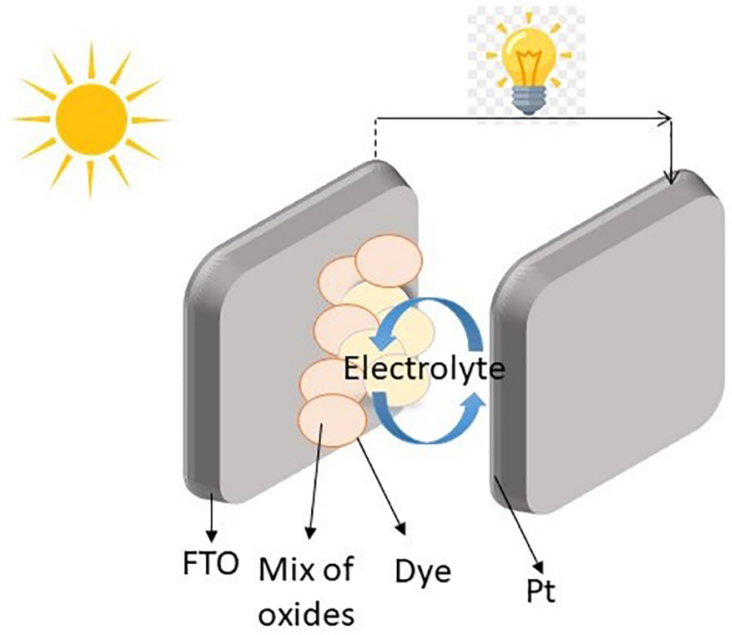

Figure 1. Schematic of a DSSC with dye N719.

Sensitization of the sample was made with immersion in dye di-tetrabutylammonium cis-bis(isothiocyanate)bis (2,2' - bipyridyl - 4,4'- dicarboxylate) ruthenium(II) (N-719, Sigma Aldrich) at $24 \mathrm{~h}$. Platinum was used as the counter electrode, platinum was electrodeposited using $\mathrm{K}_{2} \mathrm{PtCl}_{6}$ and cyclic voltammetry about conductive glass substrate on fluorine-doped tin oxide (FTO; ca.7 $\Omega \mathrm{sq}^{-1}$ ) FTO and the electrolyte was an iodide/triiodide solution. The cells were produced in a sandwich with an area of $0.2 \mathrm{~cm}^{2}$, the anode being the FTO coated with oxide films/N-719 and the cathode an FTO deposited with platinum.

\section{Results and Discussion}

\subsection{Characterization of niobium pentoxide}

The DRX confirm the production of niobium pentoxide by Pechini method with high crystallinity and free of impurities and the orthorhombic crystalline structure to $\mathrm{Nb}_{2} \mathrm{O}_{5}$, according to PDF 96-210-6535 of ICDD ${ }^{16,17,18}$. In general, the crystallization conditions of each $\mathrm{Nb}_{2} \mathrm{O}_{5}$ structure depends on the starting materials, synthesis methods and heat treatment conditions. The $\mathrm{T}-\mathrm{Nb}_{2} \mathrm{O}_{5}$ (orthorhombic structure) was obtained heating the oxide to $700^{\circ} \mathrm{C}$. In particular, the $\mathrm{T}-\mathrm{Nb}_{2} \mathrm{O}_{5}$ net parameters are: $\mathrm{a}=6.17 \AA ; \mathrm{b}=29.32 \AA ; \mathrm{c}=$ $3.94 \AA$, and its crystalline structures consist of $4 \times 4$ blocks of corner-shared $\mathrm{NbO}_{6}$ octahedra, with connected blocks sharing the edges of the octahedron ${ }^{15,16}$.

Figure 2 presents the FTIR spectrum of $\mathrm{ZnO}$ and a mix of $\mathrm{ZnO} / \mathrm{Nb}_{2} \mathrm{O}_{5}$.

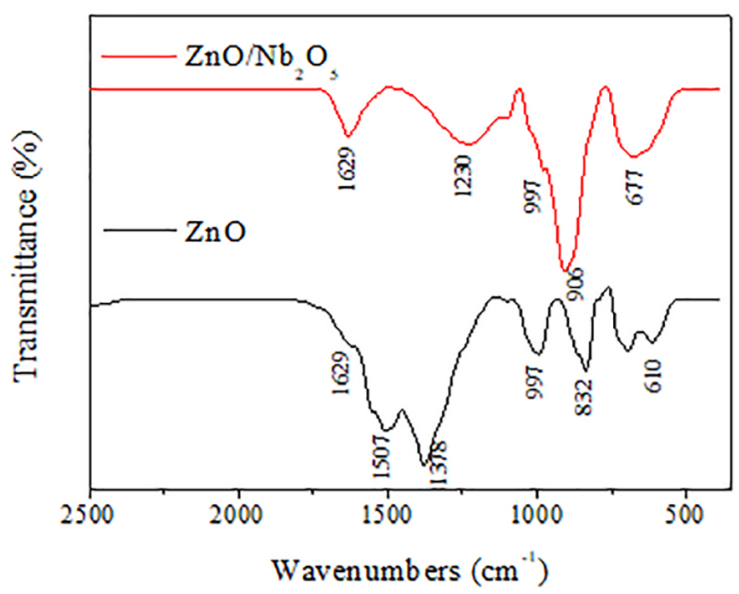

Figure 2. FTIR spectrum for the $\mathrm{ZnO}$ and the mix of $\mathrm{ZnO} / \mathrm{Nb}_{2} \mathrm{O}_{5}$.

Through analysis of FTIR shown in Figure 2, a band is observed in the region of $832-997 \mathrm{~cm}^{-1}$ that is attributed stretching of the $\mathrm{Zn}-\mathrm{O}$ band was observed that when $\mathrm{Nb}_{2} \mathrm{O}_{5}$ is added that band is shifted and intensified. A similar behavior for both diagrams is observed since bands respectively appearing in the $677-906 \mathrm{~cm}^{-1}$ region can be attributed to stretching of $\mathrm{Zn}-\mathrm{O}$ and Nb-O bonds. Already a band in 1629-1230 and $1378-1507 \mathrm{~cm}^{-1}$ for a mixture of oxide and only $\mathrm{ZnO}$ can be attributed assigned to the asymmetric stretching modes of oxygens present in sample ${ }^{18,19,20,21}$.

Figure 3 shows the X-ray fluorescence (XRF) spectrum.

The spectrum (Figure 3) presents the characteristic peaks of $\mathrm{Zn}\left(\mathrm{K}_{\alpha}\right)$ in $8.6 \mathrm{keV}, \mathrm{Zn}\left(\mathrm{K}_{\beta}\right)$ in $9.6 \mathrm{keV}$ and $\mathrm{Nb}\left(\mathrm{K}_{\alpha}\right)$ and $\mathrm{Nb}\left(\mathrm{K}_{\beta}\right)$ in $16.5 \mathrm{keV}$ and $18.6 \mathrm{keV}$ respectively and was possible to confirm the percentage of $\mathrm{Nb}_{2} \mathrm{O}_{5}, 4.70 \pm$ $0.03 \%$, on insertion in $\mathrm{ZnO}, 95.25 \pm 0.12 \%$, disregarding the presence of oxygen (the equipment does not read the oxygen element).

\subsection{Photochronoamperometry (PCA) measurement}

The photocronoamperometry technique was used to evaluate the current density in samples with only $\mathrm{ZnO}$ and addition of $\mathrm{Nb}_{2} \mathrm{O}_{5}$ and also provides information on the stability of the solar cell. In the PCA investigation, light is irradiated on the device for a given period and is then interrupted, followed by monitoring of the short-circuit current ${ }^{8}$. 


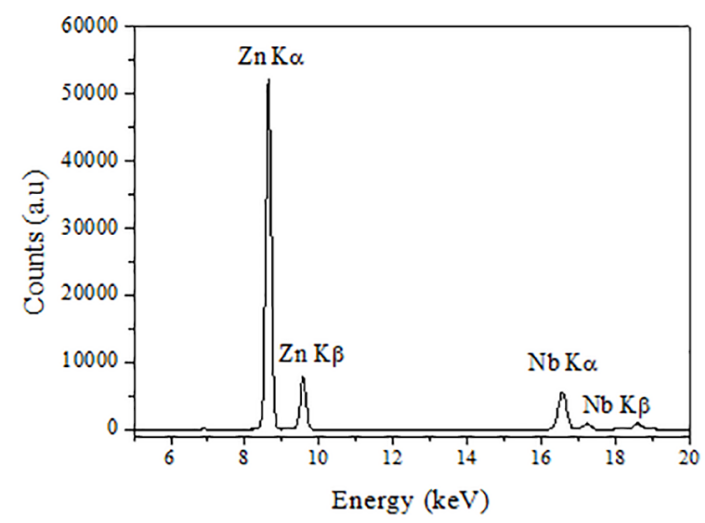

Figure 3. $\mathrm{XRF}$ spectra for mixture $\mathrm{ZnO} / \mathrm{Nb}_{2} \mathrm{O}_{5}$.

Figure 4 shows the PCA curves of solar cell compounds $\mathrm{ZnO}$ and $\operatorname{mix} \mathrm{ZnO} / \mathrm{Nb}_{2} \mathrm{O}_{5}$.

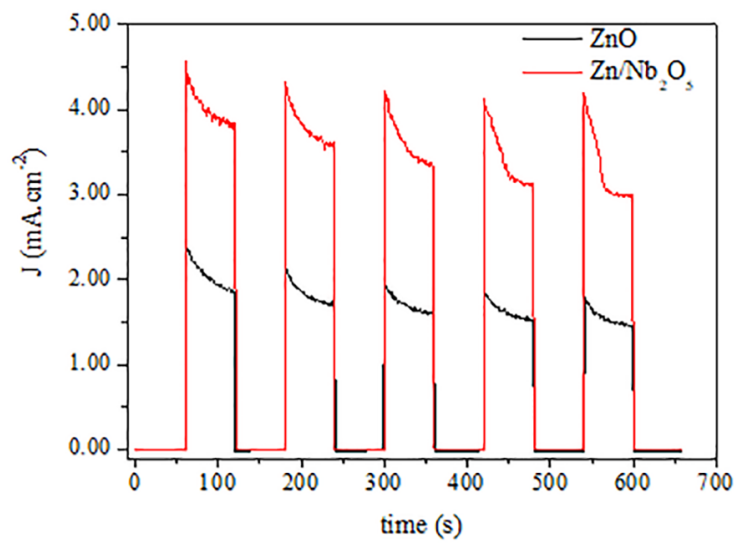

Figure 4. Photochronoamperometry for solar cells under $100 \mathrm{~mW}$ $\mathrm{cm}^{2}$ illumination with the light on and off in the $60 \mathrm{~s}$ range.

The current density curves (Figure 4) showed decay during illumination, indicating the device is diffusion-limited. As the electrolyte, which regenerates the dye, stay in the reduced state the oxidized dye molecules have to wait for more redox pairs to diffuse into the photo-anode ${ }^{21,22}$. Over time, an increasing number of dye molecules are left in the oxidized state and, therefore, a decrease in the photocurrent is observed. The cells studied presented similar behaviors, in which the film with the only $\mathrm{ZnO}$ presented a lower current density, $2.701 \mathrm{~mA} \mathrm{~cm}^{-2}$, in relation to the film with the mixture of the oxides. Where the $\mathrm{ZnO} / \mathrm{Nb}_{2} \mathrm{O}_{5}$ film obtained the current density at the beginning $(60 \mathrm{~s})$ of $4.56 \mathrm{~mA} . \mathrm{cm}^{-2}$ after $600 \mathrm{~s}$ it presented a current density of $3.02 \mathrm{~mA} . \mathrm{cm}^{-2}$, already the film with only $\mathrm{ZnO} \mathrm{J}=1.46 \mathrm{~mA} \cdot \mathrm{cm}^{-2}$.

\subsection{Characterization $J_{s c}$ vs $V_{o c}$ curves of solar cells}

Figure 5 is shown the curves $\mathrm{JxV}$ of the $\mathrm{ZnO}$ and mix $\mathrm{ZnO} / \mathrm{Nb}_{2} \mathrm{O}_{5}$.

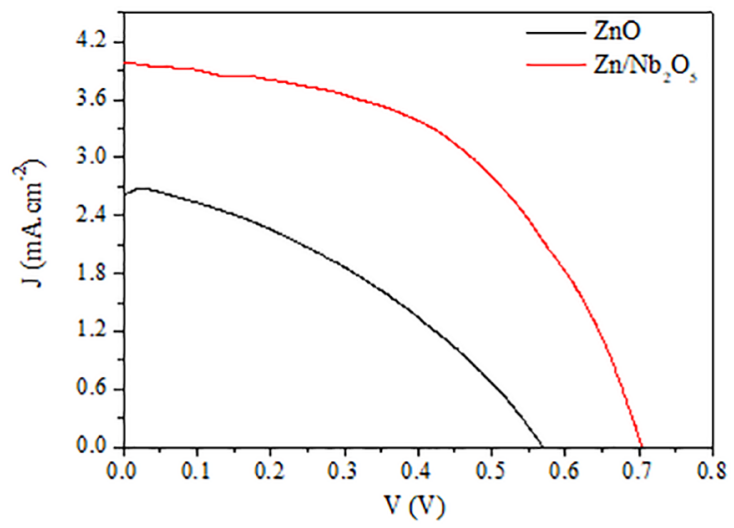

Figure 5. Curves $\mathrm{J}-\mathrm{V}$ obtained under lighting of $100 \mathrm{~mW} \mathrm{~cm} \mathrm{~m}^{-2}$ in the solar cells based on $\mathrm{ZnO} / \mathrm{Nb}_{2} \mathrm{O}_{5}$ films and only $\mathrm{ZnO}$.

The current density as a function of potential $(\mathrm{J}-\mathrm{V})$ and gives the photoelectrochemical parameters for the calculation of the efficiency of the system, using Equation 1.

$$
\eta=\left(\frac{J_{s c} \times V_{o c} \times F F}{I_{o}}\right) \times 100 \%
$$

Equation 1

Where $\mathrm{J}_{\mathrm{sc}}$ is equivalent the short-circuit density, FF, the fill factor, $\mathrm{V}_{\mathrm{oc}}$ is open-circuit potential and $\mathrm{I}_{\mathrm{o}}$ is the flux of photons irradiated, $\mathrm{I}_{\mathrm{o}}=100 \mathrm{~mW} \mathrm{~cm}^{-2}$. The values of $\mathrm{J}_{\mathrm{sc}}$ and $\mathrm{V}_{\mathrm{oc}}$ are obtained by considering the points where the voltage and current are respectively zero in this curve. The current density $\left(\mathrm{J}_{\mathrm{sc}}\right)$ is related to the absorption of the dye in a semiconductor oxide; already open circuit potential is related to the processes of charge recombination ${ }^{18}$.

Table 1 presents the parameters of the solar cells drawn from the J-V curves (Figure 5) and from Equation 1.

Table 1. Photovoltaic parameters of dye-sensitized solar cells N719.

\begin{tabular}{lcccc}
\hline $\mathrm{DSSC}$ & $\mathrm{J}_{\mathrm{sc}} / \mathrm{mA} \cdot \mathrm{cm}^{-2}$ & $\mathrm{~V}_{\mathrm{oc}} / \mathrm{V}$ & $\mathrm{FF}$ & $\eta / \%$ \\
\hline $\mathrm{ZnO}$ & 2.701 & 0.569 & 0.369 & 0.57 \\
$\mathrm{ZnO} / \mathrm{Nb}_{2} \mathrm{O}_{5}$ & 3.995 & 0.704 & 0.504 & 1.42 \\
\hline
\end{tabular}

In Figure 5 was observed that the cell with the addition of $\mathrm{Nb}_{2} \mathrm{O}_{5}$ presented the highest values of $\mathrm{J}_{\mathrm{sc}}$, this being 3.995 $\mathrm{cm}^{-2}$. The current produced by the cell is associated with the 
electron injection mechanism and the charge transport of the carriers ${ }^{1,18}$. The addition of $\mathrm{Nb}_{2} \mathrm{O}_{5}$ increased the efficiency values, being the cell containing $\mathrm{Nb}_{2} \mathrm{O}_{5}$, presenting efficiency of e de $\eta=1.42 \%$, while the cell constituted only by $\mathrm{ZnO}$ showed the efficiency of $0.57 \%$. The increase in efficiency values indicates that the addition of niobium changes the electrical properties of zinc oxide en-24. $^{22}$.

Table 1 shows that the cell with addition of $\mathrm{Nb}_{2} \mathrm{O}_{5}$ presents an increase in the value of $\mathrm{V}_{\mathrm{oc}}$ in relation to the cell using the only $\mathrm{ZnO}$, indicating that when adding $\mathrm{Nb}_{2} \mathrm{O}_{5}$ occurs an increase of the lifetime of the electron as consequence of the decrease of the recombination processes ${ }^{24}$. The lowest value of circuit potential in $\mathrm{ZnO}$ cell is attributed the oxygen vacancies where the excited electrons that were released from the dye to the $\mathrm{ZnO}$ will be deactivated to fill those energy levels that are located between the conduction band of zinc oxide, reducing the photocurrent and the efficiency of the solar cell. When added to the $\mathrm{Nb}_{2} \mathrm{O}_{5}$ these vacancies are decreased by increasing the in the value of Voc increasing consequently the lifetime of the electron ${ }^{2-23}$.

\section{Conclusion}

The analysis of X-ray diffraction, X-ray fluorescence and infrared spectroscopy incated that the particles of niobium oxide was formed and are present in the mixture with $\mathrm{ZnO}$.

The addition of $\mathrm{Nb}_{2} \mathrm{O}_{5}$ in $\mathrm{ZnO}$ on DSSC provided an effective improvement in the photovoltaic parameters. PCA showed that the current density value was twice as highest $\left(\mathrm{ZnO} / \mathrm{Nb}_{2} \mathrm{O}_{5}, \mathrm{~J}=3.02 \mathrm{~mA} . \mathrm{cm}^{-2}\right)$ as the $\mathrm{ZnO}$ cell $\left(\mathrm{J}=1.46 \mathrm{~mA} \cdot \mathrm{cm}^{-2}\right)$. The efficiency value of the $\mathrm{ZnO} / \mathrm{Nb}_{2} \mathrm{O}_{5}$ cell presented an increase approximately of $200 \%$ to the cell $\mathrm{ZnO}$. Others parameters as $\mathrm{J}_{\mathrm{sc}}, \mathrm{V}_{\mathrm{oc}}$ and FF presented in the $\mathrm{J}-\mathrm{V}$ curve indicate that the presence of niobium oxide minimized the charge recombination processes and that the electrical properties of the zinc oxide were also altered.

\section{Acknowledgments}

This study was financed in part by the Coordenação de Aperfeiçoamento de Nível Superior- Brasil (CAPES) Finance Code 001.

\section{References}

1. Maia GAR, Larsson LFG, Viomar A, Matos LAC, Antunes SRM, Maia ECR, et al. Influence of zinc oxide morphology in hybrid solar cells of poly(3-octylthiophene). Journal of Materials Science: Materials in Electronics. 2016;27(8):8271-8278.

2. Ebadi M, Zarghami Z, Motevalli K. $40 \%$ Efficiency enhancement in solar cells using $\mathrm{ZnO}$ nanorods as shell prepared via novel hydrothermal synthesis. Physica E: Low-dimensional Systems and Nanostructures. 2017;87:199-204.
3. Anuntahirunrat J, Sung YM, Pooyodying P. Efficiency of $\mathrm{Nb}$-Doped $\mathrm{ZnO}$ Nanoparticles Electrode for Dye-Sensitized Solar Cells Application. IOP Conference Series: Materials Science and Engineering. 2017;229:012019.

4. Anta AJ, Guillén E, Tena-Zaera R. ZnO-Based Dye-Sensitized Solar Cells. The Journal of Physical Chemistry C. 2012;116(21):1141311425 .

5. Ueno S, Fujihara S. Effect of an $\mathrm{Nb}_{2} \mathrm{O}_{5}$ nanolayer coating on $\mathrm{ZnO}$ electrodes in dye-sensitized solar cells. Electrochimica Acta. 2011;56(7):2906-2913.

6. Apostolopoulou A, Karageorgopoulos D, Rapsomanikis A, Stathatos E. Dye-Sensitized Solar Cells with Zinc Oxide Nanostructured Films Made with Amine Oligomers as Organic Templates and Gel Electrolytes. Journal of Clean Energy Technologies. 2016;4(5):311-315.

7. Green ANM, Palomares E, Haque SA, Kroon JM, Durrant JR. Charge Transport versus Recombination in Dye-Sensitized Solar Cells Employing Nanocrystalline $\mathrm{TiO}_{2}$ and $\mathrm{SnO}_{2}$ Films. The Journal of Physical Chemistry B. 2005;109(25):12525-12533.

8. Nunes VF, Souza APS, Lima F, Oliveira G, Freire FN, Almeida AF. Effects of Potential Deposition on the Parameters of $\mathrm{ZnO}$ dye-sensitized Solar Cells. Materials Research. 2018;21(4):e20170990.

9. Katoh R, Furube A, Yoshihara T, Hara K, Fujihashi G, Takano $\mathrm{S}$, et al. Efficiencies of Electron Injection from Excited $\mathrm{N}_{3}$ Dye into Nanocrystalline Semiconductor $\left(\mathrm{ZrO}_{2}, \mathrm{TiO}_{2}, \mathrm{ZnO}, \mathrm{Nb}_{2} \mathrm{O}_{5}\right.$, $\mathrm{SnO}_{2}, \mathrm{In}_{2} \mathrm{O}_{3}$ ) Films. The Journal of Physical Chemistry $B$. 2004;108(15):4818-4822.

10. Zhang J, Peng W, Chen Z, Chen H, Han L. Effect of Cerium Doping in the $\mathrm{TiO}_{2}$ Photoanode on the Electron Transport of Dye-Sensitized Solar Cells. The Journal of Physical Chemistry C. 2012;116(36):19182-19190.

11. Le Viet A, Jose R, Reddy MV, Chowdari BVR, Ramakrishna S. $\mathrm{Nb}_{2} \mathrm{O}_{5}$ Photoelectrodes for Dye-Sensitized Solar Cells: Choice of the Polymorph. The Journal of Physical Chemistry C. 2010;114(49):21795-21800.

12. Ok MR, Ghosh R, Brennaman MK, Lopez R, Meyer TJ, Samulski ET. Surface Patterning of Mesoporous Niobium Oxide Films for Solar Energy Conversion. ACS Applied Materials \& Interfaces. 2013;5(8):3469-3474.

13. Bandara J, Weerasinghe HC. Enhancement of photovoltage of dye-sensitized solid-state solar cells by introducing highband-gap oxide layers. Solar Energy Materials and Solar Cells. 2005;88(4):341-350.

14. Kim SG, Ju MJ, Choi IT, Choi WS, Choi HJ, Baek JB, et al. $\mathrm{Nb}$-doped $\mathrm{TiO}_{2}$ nanoparticles for organic dye-sensitized solar cells. RSC Advances. 2013;3(37):16380-16386.

15. Viomar A, Maia GAR, Scremin FR, Khalil NM, Cunha MT, Antunes AC, et al. Influência do Método de Obtenção de Partículas de $\mathrm{Nb}_{2} \mathrm{O}_{5}$ Empregadas em Células Solares Sensibilizadas por Corante Compostas de $\mathrm{TiO}_{2} / \mathrm{Nb}_{2} \mathrm{O}_{5}$. Revista Virtual de Química. 2016;8(3):889-900. 
16. Raba AM, Bautista-Ruíz J, Joya MR. Synthesis and Structural Properties of Niobium Pentoxide Powders: A Comparative Study of the Growth Process. Materials Research. 2016;19(6):1381-1387.

17. Rincón Joya M, Barba Ortega JJ, Raba Paez AM, Silva Filho JG, Freire PTC. Synthesis and Characterization of Nano-Particles of Niobium Pentoxide with Orthorhombic Symmetry. Metals. 2017;7(4):142.

18. Tractz G, Maia GAR, Dias BV, Ignachewski F, Rodrigues PRP. Avaliação da adsorção e estudo eletroquímico de células solares produzidas com $\mathrm{TiO}_{2}$ e corante extraído do hibiscus. Química Nova. 2018;41(5):512-518.

19. Gonçalves CL, Corazza ML, Oliveira MM, Rangel JHG, Vasconcelos JS, Figueredo GP, et al. Synthesis and characterization of $\mathrm{SnO}_{2} \cdot \mathrm{Nb}$ catalysts supported on Maranhão clay. Revista Matéria. 2018;23(1):e-11972.

20. Rajendran SP, Sengodan K. Synthesis and Characterization of Zinc Oxide and Iron Oxide Nanoparticles Using Sesbania grandiflora Leaf Extract as Reducing Agent. Journal of Nanoscience. 2017;2017:8348507.
21. Saitoh A, Brow RK, Hoppe U, Tricot G, Anan S, Takebe H. The structure and properties of $\mathrm{xZnO}-(67-\mathrm{x}) \mathrm{SnO}-\mathrm{P}_{2} \mathrm{O}_{5}$ glasses: (I) optical and thermal properties, Raman and infrared spectroscopies. Journal of Non-Crystalline Solids. 2018;484:132-138.

22. Dias BV, Tractz GT, Viomar A, Maia GAR, da Cunha MT, Rodrigues PRP. Photoelectrochemical Behavior of the Cell FTO/ $\mathrm{TiO}_{2} / \mathrm{CeO}_{2} / \mathrm{N} 719$ Obtained from the Pechini and Precipitation of Cerium Oxide Methods. Journal of Electronic Materials. 2018;47(9):5556-5563.

23. Essner J. Dye sensitized solar cells: optimization of Grätzel solar cells towards plasmonic enhanced photovoltaics. [Thesis]. Manhattan, KS: Kansas State University; 2011.

24. Sacco A, Di Bella MS, Gerosa M, Chiodoni A, Bianco S, Mosca M, et al. Enhancement of photoconversion efficiency in dye-sensitized solar cells exploiting pulsed laser deposited niobium pentoxide blocking layers. Thin Solid Films. 2015;574:38-42. 